\title{
How Single TaXes ImPaCt THE CONVERGENCE OF THE TAXation IN THE EUROPEAN UNION
}

\author{
Monika Bušovská ${ }^{1}$; Ladislav Bušovský ${ }^{2}$ \\ University of Economics Prague, Faculty of Finance and Accounting, \\ Department of Public Finance, \\ Winston Churchill Square 4, 130 67, Prague 3, Czech Republic \\ e-mail: ${ }^{1}$ xbusm04@vse.cz; ${ }^{2}$ xbus101@vse.cz
}

\begin{abstract}
As a result, the original purely economic-oriented cooperation gave birth to a community named the European Union, which is now cooperating in a number of areas, not excluding the tax policy issues. This paper results from works which point out the tax convergence in the EU. The aim of this paper is to quantify the impact of the tax mix and tax competition on the convergence of tax systems in the EU. The empirical part of the paper makes use of the panel regression with fixed-effects for the 28 EU countries between the years 1965 and 2011. Two designed models report a statistically significant positive impact of all determinants on the effective tax burden. On the basis of final values, tax competition and property taxes have been assessed as the most important determinants of tax convergence. All models meet diagnostic tests and are econometrically robust. The obtained results can be considered as relevant with sufficient information capability.
\end{abstract}

\section{Introduction}

Increasing globalization and the European Union (hereinafter referred to as "EU") enlargement have an influence not only on human culture or politics, but mainly on the economies of the countries in which integration is on different levels of their development [1].

The first step in the European integration consisted of strengthening the economic cooperation between the member states whose goal was to establish a single market. That means free movement of goods, persons, services, and capital [1] and the introduction of a common currency, the Euro [2].

The homogeneity in terms of the tax burden of individual member states may be questionable [3]. Due to the existence of differences in economic structures and political preferences, together with national fiscal autonomies, the European tax systems are far from being uniform. However, the European Union has been trying to converge tax systems, which should lead to the removal of all obstacles to the creation of the single market.

Tax-coordination, as a tool for avoiding the emergence of very diverse politics, and taxharmonization, as a tool for the approximation of tax systems, has been the subject of much debate since the beginning of the European integration. The issues of the coordination, approximation, and harmonization of the tax systems in the EU are discussed, for instance, in [4], [5], [6], [7], who make readers familiar with various directives and regulations that affect the tax systems of the member states.

However, tax convergence has supporters as well as opponents. Cultural dissimilarities and freedom of adopting tax legislation, which are based on different structures, are the main arguments to reject the convergence of taxes. Another negative aspect is a loss of tax competitiveness of individual Member States [8]. Serna [4] believes that convergence is 
a positive phenomenon because it reduces the scope of "unfair" tax arbitrage for the price of higher transaction costs. All member states would be able to benefit from the single tax system and no distortions would emerge. He prefers full harmonization and integration. Thus it is evident that since the EU establishment, there have been continuous clashes of views in the EU regarding the question whether to maintain tax competition or rather press for tax harmonization.

Kubátová [10] pursued the controversy between tax harmonization and competition as well, and she came to the conclusion that it was impossible to identify the more favourable one tax competition or harmonization. In her work, she draws attention to the fact that tax harmonization brings the threat of the disproportionate growth of tax burden borne by taxpayers, and if not applied within the whole territory of the community, it is ineffective. However, according to this author, competition in taxes can cause under-sizing of the public sector under the tolerable rate and it can bring a risk of tax-overload of immobile bases, especially work. Nevertheless, tax competition itself should lead to the convergence of taxation systems as well because the reduction of the tax burden in one state will cause the growth of tax incomes by the relocation of tax bases and the outflow of tax revenues of other states. In order to prevent this phenomenon, they will reduce their tax burden too and according to economic theory, the whole process leads to the convergence of tax burden in one area [11].

Nerudová [12] states that tax competition should result in a responsible, complex and effective tax policy with a lower tax burden, which produces the positive and effective climate for a greater economic growth.

In her work on the impact of tax competition on economic growth, Szarowská str. 40 [13] defined tax competition as "A process of lowering effective tax burden to make investors and factors of production owners allocate their tax bases in a given country, provided that identical conditions are respected for all subjects."

In spite of these problems there are lots of authors who have been trying to find out whether taxation converges in the EU. Foltysová [14] and Serna [15] deal with a cluster analysis of 22 OECD countries in several time periods between 1965 and 2003. They make use of five chosen main variables of the tax structure in accordance with the OECD classification. They conclude that the tax structure in the EU has become closer in four main groups - northern, southern, central European and non-European.

De Brandt and Mongelli [16] monitors the convergence of tax burden in the EU on the basis of set economic, financial, monetary and institutional factors using correlations and cointegration analysis between 1970-1998. Their conclusions suggest that in the euro-area countries fiscal dispersion constantly decreases.

Drawing on the $\beta$-convergence and $\sigma$-convergence methodology, [17], [18], and [19] infers that tax burden converges between 1967 and 1995 during an annual data analysis of $15 \mathrm{EU}$ countries; with the only exception in the period from 1974 to 1984 . The same methodology including unit root tests is used by [20], [21] and [22], whose key contribution is attached to the evidence that tax convergence in the EU occurs during the whole 1965-2005 period.

In their works, Bušovská [23], Bušovská [24] and Bušovská and Petrovická [25] address tax burden convergence by means of $\beta$-convergence and $\sigma$-convergence from several points of view. They analyse statutory tax rates but also implicit tax rates, which give a true picture of the real tax burden of different economic activities, but especially compound tax quotas and their tax structures. According to her analyses, the effective tax burden itself converges in the 
EU between 1965 and 2011. These conclusions are used for subsequent research included in this work as well as the definition of tax competition taken from the work by Szarowská [13].

Aim

The article will try to answer:

a) To what degree tax burden components influence the convergence of tax systems in the EU countries.

b) To what degree tax competition influences the convergence of tax systems in the EU countries.

\section{$2 \quad$ Methodology}

The work uses methods of comparison, classification methods and deductive methods with the analogy method. The analysis method is important, supplemented by the synthesis method for the creation of a coherent objective opinion in the conclusion of the work.

Firstly, it is necessary to identify individual terms and define their meaning.

The easiest way to determine the tax burden is the use of statutory rates of taxes [24]. However, Blechová [26] emphasises in her research that statutory tax rates do not fully play the role of an objective indicator for the international comparison, which is why the so called implicit tax rates are used within the scope of tax rates. They measure the average effective tax burden of various kinds of economic incomes and activities. In other words, implicit rates inform about the percentage from the given economic activity that is paid to the state through taxes, including social allowances concerning labour [26]. This methodology is used, e.g., by European Commision [27], Ř́hová [28], Petráňová [29] and Bušovská [24].

The tax quota can also be applied for the international comparison of tax burden by Kubátová [7] and Szarowská [13]. It represents a macroeconomic indicator which is set as the ratio of tax and customs revenues to the GDP in going prices. Thus the tax quota (also called tax burden) represents a certain proportion of the GDP which is redistributed by means of public budgets. This indicator uses information on the tax incomes actually collected for the GDP by means of which it can inform about the value of the overall effective taxation figure in a given country. Nonetheless, the tax quota is the simple tax quota which represents the revenue proportion of individual taxes (without social insurance contributions) of the GDP. On the other hand, the compound tax quota is more relevant because it expresses the share of all taxes (including social insurance contributions) in the GDP (also called total tax burden shortcut TTB) [7]. The example of the total tax burden in the world is shown in Fig. 1.

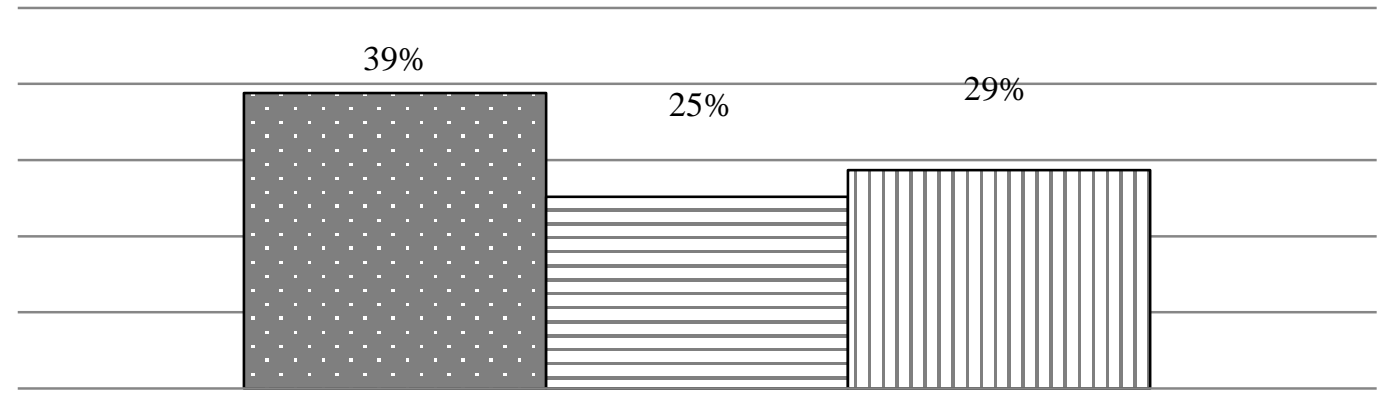
$\square$ EU 28
$\square$ USA
$\square$ Japan

Source: EC (2010), own processing

Fig. 1: Total tax burden in the world (\%) 
Tax mix represents the proportion of individual taxes of the total tax revenue (tax quota). This indicator informs whether a country prefers direct or indirect taxes [13].

Tab. 1: Example of the tax mix of the Czech Republic in 2011

\begin{tabular}{|c|c|c|c|}
\hline Income taxes $(I T)$ & $20.34 \%$ & Payroll tax 1 (Payroll) & $1.75 \%$ \\
\hline Social security contribution $(S C)$ & $44.06 \%$ & Tax on goods and services (Indir) & $33.84 \%$ \\
\hline Other taxes (Other) & $0.01 \%$ & Tax on property (Property) & $<0.00 \%$ \\
\hline
\end{tabular}

For the above stated reasons, the compound tax quota and its individual components classified according to the OECD classification will be used to achieve the objective. In this work, gross domestic product (hereinafter referred to as "GDP") is considered in common prices in the purchasing power parity. The reason for this decision dwells from the fact that this representation eliminates the differences in price levels among countries and allows us to compare even economies which markedly differ in the absolute magnitude. Purchasing power parity is an artificially created monetary unit used in international comparisons to express the volume of economic overall indicators.

The term "European Union" denotes a community of 28 EU member states. The panel regression analysis is based on the annual data of the EU countries since 1965 and the end of the individual time series is stipulated by 2011, which represents the most up-to-date period of time at the time of the analysis of the given issues. The data source comprises secondary information provided by OECD [30]. Tax shares are classified in accordance with OECD classes [31] and the missing data are not considered.

According to Novák [32], convergence means reducing the difference in time between two quantities. If $y_{1, t}$ and $y_{2, t}$ are relevant economic quantities of two countries within time $t$, then convergence in the period between $t$ and $t+s$ means:

$$
\left|y_{1, t}-y_{2, t}\right|>\left|y_{1, t+s}-y_{2, t+s}\right|
$$

The aforesaid claim holds true for the exploration of convergence between two countries. The standard deviation or $\sigma$-convergence used by Szarowská [13] in her work represents a parallel for a group of countries. For the formation of individual models of the panel regression analysis, this work draws on the conclusions of works by Foltysová [14], Kubátová [15], Sosvilla and Tamarit [18], Sosvilla et al. [19], Delgado and Presno [20], Delgado and Presno [21], Rivero and Casquero [22], Bušovská [24], and Bušovská [25], which proved the taxation of European states converge by $\beta$-convergence a $\sigma$-convergence. The econometric analysis and the related calculations are made in programmes Gretl 1.9. and Eviews 7.2. For individual residues, the work uses the following abbreviations presented by the Table 2 .

In view of the fact that it is a time series analysis between 1965 and 2011, it is always necessary to check whether time series are stationary when working with them. The works by contemporary authors suggest unit roots tests of panel data which have a greater power than unit roots tests used for checking the stationarity of one-dimensional time series [33]. We can mention tests by these authors: Levin et al. [34] - test LLC, Im et al. [35] - test IPS, Maddala [36], [37] - Fisher-ADF test and Fisher-PP test.

These tests are used in the presented work as well. Their explanatory power according to the null hypothesis $\left(\mathrm{H}_{0}: \rho=1\right)$ confirms that the monitored time series includes the unit root (it is not stationary). Thus if this is possible, we can reject the null hypothesis. The time series is stationary and it is possible to work with it for panel regression purposes. 
Tab. 2: Abbreviations used in the paper

\begin{tabular}{|l|l|l|l|}
\hline Shortcut & Name & Shortcut & Name \\
\hline TTB & Total tax burden & SC & $\begin{array}{l}\text { Social contribution (tax } \\
\text { revenues) }\end{array}$ \\
\hline IT & $\begin{array}{l}\text { 1st difference of time period of } \\
\text { total tax burden }\end{array}$ & Payroll & $\begin{array}{l}\text { Taxes on wages and salaries (tax } \\
\text { revenues) }\end{array}$ \\
\hline PIT & $\begin{array}{l}\text { Personal income taxes (tax } \\
\text { revenues) }\end{array}$ & Indir & Indirect taxes (tax revenues) \\
\hline dPIT & $\begin{array}{l}\text { 1st difference of time period of } \\
\text { personal income taxes (tax } \\
\text { revenues) }\end{array}$ & dProperty & $\begin{array}{l}\text { Taxes on property (tax revenues) } \\
\text { taxes on property (tax revenues) }\end{array}$ \\
\hline CIT & $\begin{array}{l}\text { Corporate income taxes (tax } \\
\text { revenues) }\end{array}$ & Other & Other taxes (tax revenues) \\
\hline dCIT & $\begin{array}{l}\text { 1st difference of time period of } \\
\text { corporate income taxes (tax } \\
\text { revenues) }\end{array}$ & dOther & $\begin{array}{l}\text { 1st difference of time period of } \\
\text { other taxes (tax revenues) }\end{array}$ \\
\hline
\end{tabular}

Source: own processing

Consequently, the work uses the panel regression analysis or panel data analysis which concerns the analysis of relations and the connection of the data in a two-dimensional space. The first dimension is made by time quantity, the second dimension is represented by the cross-section data of individual monitored objects. A panel stands for a set of units which are similar or related by some characteristic qualities and which are continuously monitored [33]. A necessary precondition for the possibility of defining a panel and subsequent panel data analysis is that the set of units does not change in time and the missing units are not replaced by new ones. A general estimating equation is as follows:

$$
y_{i t}=\alpha+\beta^{\prime} x_{i t}+\delta_{i}+\varepsilon_{i t}
$$

where

$y_{i t}$ is the explained variable,

$x_{i t}$ is $k$-vector of explanatory variables,

$\varepsilon_{i t}$ is residual component of the model,

$i=1 \ldots N$ cross-section units,

$t=1 \ldots T$ time (data flow in time),

$\alpha$ is overall constant of the model,

$\beta^{\prime}$ are parameters (coefficients) representing the slope of variables,

$\delta_{i}$ is cross-section effects and

$\gamma_{t}$ time (periodic) effect.

When using the regression analysis, there are always at least two possibilities: the application of the regression analysis with random effects or fixed effects. Nevertheless, according to Dougherty [38], we cannot suppose that in the case of the panel of the EU countries these countries are a random sample of all sovereign states in the world. Thus it is necessary to make use of the regression analysis with fixed effects. To confirm this hypothesis, the outcomes of the Durbin-Wu-Hausman test was also used and the identified value confirmed 
that it is really more adequate to use a panel regression model with fixed effects [39]. A properly constructed model also should not show autocorrelation, which is why the Durbin-Watson test [40] is used in the work.

The paper does not handle the issue of tax construction or the choice of optimal tax system; it also does not deal with the question of tax justice or processes and instruments of the EU tax policy. Model results from papers of Foltysová [14], Kubátová [15], Delgado and Presno [20], Delgado and Presno [21], Rivero et al. [22], and Bušovská [24].

For the foundation of the whole work the methodology of new Keynesian economics was adopted. It states that the econometric model can only help reveal the relations among variables, but its conclusions do not confirm nor disprove the validity of the economic theory. For this reason, it is impossible to draw recommendations for the economic policy from the outcomes of the model.

\section{$3 \quad$ Results and Discussion}

\subsection{Panel tests of data}

Panel unit root tests have shown that most time series are already stationary at a $1 \%$ significance level, which makes it possible to use the data for the purpose of the panel regression analysis. The exceptions comprise the compound tax quota (TTB), tax revenues from income tax (IT), personal income taxes (PIT), corporate income taxes (CIT), property taxes (Property) and payroll taxes (Payroll), where it was necessary to use the first definition so that time series could show stationarity. For further information see the Table 3.

Tab. 3: Panel unit root tests

\begin{tabular}{|c|c|c|c|c|c|c|c|c|c|c|c|c|}
\hline $\begin{array}{l}\text { Unit Root } \\
\text { Test }\end{array}$ & TTB & Prob & Obs & $\begin{array}{c}\text { TTB } \\
\text { 1.difer }\end{array}$ & Prob & Obs & SC & Prob & Obs & Indir & Prob & Obs \\
\hline LLC & -0.827 & 0.204 & 769 & -11.796 & 0.000 & 748 & -3.641 & 0.000 & 772 & -2.538 & 0.005 & 772 \\
\hline IPS & -1.067 & 0.143 & 769 & -14.571 & 0.000 & 748 & -3.137 & 0.000 & 772 & -3.442 & 0.000 & 772 \\
\hline Fisher ADF & 49.493 & 0.199 & 769 & 303.091 & 0.000 & 748 & 76.998 & 0.000 & 772 & 82.600 & 0.000 & 772 \\
\hline Fisher PP & 51.398 & 0.152 & 790 & 489.211 & 0.000 & 769 & 62.733 & 0.021 & 793 & 87.779 & 0.000 & 793 \\
\hline & CIT & Pro. & Obs & CIT 1.difer & Prob & Obs & PIT & Prob & Obs & $\begin{array}{c}\text { PIT } \\
\text { 1.difer }\end{array}$ & Prob & Obs \\
\hline LLC & -0.069 & 0.474 & 747 & -10.467 & 0.000 & 726 & 0.083 & 0.533 & 945 & -7.751 & 0.000 & 924 \\
\hline IPS & -4.389 & 0.000 & 747 & -15.766 & 0.000 & 726 & 0.504 & 0.693 & 945 & -12.838 & 0.000 & 924 \\
\hline Fisher ADF & 88.540 & 0.000 & 747 & 328.133 & 0.000 & 726 & 38.223 & 0.633 & 945 & 256.156 & 0.000 & 924 \\
\hline Fisher PP & 182.859 & 0.021 & 768 & 615.734 & 0.021 & 747 & 39.343 & 0.588 & 966 & 534.493 & 0.000 & 925 \\
\hline & Property & Prob & Obs & $\begin{array}{c}\text { Property } \\
\text { 1.difer }\end{array}$ & Prob & Obs & Payroll & Prob & Obs & $\begin{array}{c}\text { Payroll } \\
\text { 1.difer } \\
\end{array}$ & Prob & Obs \\
\hline LLC & -1.506 & 0.066 & 771 & -12.077 & 0.000 & 750 & 2.769 & 0.997 & 772 & -4.054 & 0.000 & 751 \\
\hline IPS & -0.156 & 0.437 & 771 & -16.793 & 0.000 & 750 & -4.156 & 0.000 & 772 & -14.899 & 0.000 & 751 \\
\hline Fisher ADF & 43.746 & 0.397 & 771 & 345.523 & 0.000 & 750 & 84.243 & 0.000 & 772 & 315.904 & 0.000 & 751 \\
\hline Fisher PP & 73.125 & 0.002 & 792 & 562.009 & 0.000 & 771 & 372.130 & 0.000 & 793 & 798.852 & 0.000 & 772 \\
\hline & Other & Prob & Obs & & & & & & & & & \\
\hline LLC & -3.389 & 0.000 & 772 & & & & & & & & & \\
\hline IPS & -3.721 & 0.000 & 772 & & & & & & & & & \\
\hline Fisher ADF & 83.006 & 0.000 & 772 & & & & & & & & & \\
\hline Fisher PP & 66.267 & 0.009 & 793 & & & & & & & & & \\
\hline
\end{tabular}

\subsection{Panel regression model 1}

This model aims at answering the question to what extent the individual tax burden components influence the tax systems convergence in the EU countries.

In accordance with Slavík [32], the convergence of the EU tax systems, the left side of the equation is represented in the model as the difference between the compound tax quota $\left(y_{t t b}\right)$ 
of an individual member state $s(s=1 \ldots 28)$ in different years $t(t=1 \ldots 46)$ and average values in the EU countries $\left(y_{\text {ttbav }}\right)$ in the given year $t(t=1 \ldots 46)$.

The right side of the equation represents the impact of the convergence of individual tax mix components on the compound tax quota convergence as a whole (once again, the constants are specific for country $s$ and time $t), \delta_{i}$ represents fixed effects in the $s$-th observation ( $s$-th country), $\varepsilon_{i t}$ represents a residual component in time $t$ and country $s$.

For the detailed appreciation of the topic are income taxes (IT) divided into personal income taxes (PIT) and corporate income taxes (CIT). This will bring a closer ascertainment of tax competition influence, which will also allow it to be reflected from the position of investors' taxation and the one of the work owner, land and capital owner.

The influence of the individual components is calculated for:

1. Personal income taxes $P I T_{\text {l.t. }}$ as the difference $\left(y_{\text {pit.s.t }}-y_{\text {pitav.t }}\right)$.

2. Corporate taxes $C I T_{\text {l.t. }}$ as the difference $\left(y_{\text {cit.s.t }}-y_{\text {citav.t }}\right)$.

3. Social allowances $S C_{\text {s.t }}$ as the difference $\left(y_{\text {sc.s.t }}-y_{\text {scav.t }}\right)$.

4. Indirect taxes Indir ${ }_{\text {s.t }}$ as the difference $\left(y_{\text {indir.s.t }}-y_{\text {indirav.t }}\right)$.

5. Property taxes Property $y_{\text {s.t }}$ as the difference $\left(y_{\text {property.s.t }}-y_{\text {propertyav.t }}\right)$.

6. Payroll taxes Payrol s.t as the difference $\left(y_{\text {payroll.s.t }}-y_{\text {payrollav.t }}\right)$.

7. Other taxes Other $_{\text {s.t }}$ as the difference $\left(y_{\text {other.s.t }}-y_{\text {otherav.t }}\right)$.

In which the first value in brackets represents the difference of the value of a given part of the tax mix within an individual member state $s(s=1 \ldots 28)$ in different years $t(t=1 \ldots 46)$ and the average value of the given part of the tax mix in the EU countries in the given year $t$ $(t=1 \ldots 46)$. The estimating equation is as follows:

$$
\begin{gathered}
\left(y_{\text {ttb.s.t }}-y_{\text {ttbav.t }}\right)=\alpha+\beta * d \text { PIT }_{\text {s.t }}+\beta * d \text { CIT }_{\text {s.t }}+\beta * s c_{s . t}+\beta * \text { Indir }_{\text {s.t }}+ \\
+\beta * d \text { Property }_{\text {s.t }}+\beta * \text { dPayroll }_{\text {s.t }}+\beta * \text { Other }_{\text {s.t }}+\delta_{i}+\varepsilon_{i t}
\end{gathered}
$$

Table 4 presents the outcomes of the impact of individual components of the convergence of member states' tax mixes on the total tax burden convergence in the EU. To gain the results, 719 observations were used and residues of other taxes (Other) were excluded because they did not show any significant dependence in the model specified.

The calculated values show a positive dependence among variables. The increase of, e.g., personal income taxes by 1 percentage point in number states increases the tax burden convergence in the EU by $0.97 \%$ in the same year.

The given relations are statistically important already at a $1 \%$ significance level. The DurbinWatson test confirms that residues do not suffer from autocorrelation. As for the panel regression, it is more appropriate to use an adjusted determination coefficient R2 [41] which specifies that the given model clarifies about a $58 \%$ convergence value of the total tax quota in the EU.

The harmonization of indirect taxes is on a high level in the EU, both in the field of selective indirect taxes imposed on selected commodities (called consumption taxes or excise duty) and the general indirect tax which takes the form of the value added tax. The importance of this type of taxes should grow in the coming years. as stated by European Commission name [27], 
and there is an apparent trend to increase indirect taxes in many European Union countries, especially in the recent years after the outbreak of the financial crisis.

Tab. 4: Model estimation

\begin{tabular}{|l|r|r|r|r|l|}
\hline Variable & Coefficient & Standard deviation & t-test & \multicolumn{1}{|c|}{ P-value } & \\
\hline Constant $\alpha$ & -0.0777575 & 0.0297032 & -2.6178 & 0.00904 & $* * * *$ \\
\hline dCIT & 0.9847770 & 0.0706347 & 13.9418 & $<0.00001$ & $* * *$ \\
\hline dPIT & 0.9728140 & 0.0461551 & 21.0771 & $<0.00001$ & $* * *$ \\
\hline SC & 0.0606861 & 0.0233824 & 2.5954 & 0.00965 & $* * *$ \\
\hline Indir & 0.1269010 & 0.0285767 & 4.4407 & 0.00001 & $* * *$ \\
\hline dPayroll & 0.5516330 & 0.1394320 & 3.9563 & 0.00008 & $* * *$ \\
\hline dProperty & 1.0251000 & 0.0751446 & 13.6417 & $<0.00001$ & $* * *$ \\
\hline
\end{tabular}

\begin{tabular}{|l|r|}
\hline $\mathrm{R}^{2}$ & 0.5935070 \\
\hline Adjusted $\mathrm{R}^{2}$ & 0.5788430 \\
\hline Durbin-Watson test & 1.9324260 \\
\hline Number of observations & 719 \\
\hline
\end{tabular}

*. **. *** represent significant coefficient of $1 \%$ significance level

Source: OECD (2012). own processing

To a certain extent, this measure, very popular with member state governments, is induced by the fact that the increase of indirect taxes does not have to have such a negative impact on the domestic economy as the increase of direct taxes [13]; indirect taxes also represent a relatively stable and well-predictable source of income, they are hidden in the prices of goods and services, their increase can normally be implemented more easily than with the income tax, they are potentially neutral and when fulfilling certain criteria, they cannot be avoided by a change of behaviour or. e.g., by the change of residence; they also lead to a oneoff price increase and a higher inflation in the short run.

The harmonization of common Europe-wide rules goes hand in hand with the increase of indirect tax shares on the total tax burden. Here, the harmonization is at a higher level than with other taxes and. practically, it has been in progress since the beginnings of the European economic integration. Thus the relatively low level of the impact of the indirect tax convergence (Indir with the value of 0.127) on the tax burden convergence of the EU countries is not surprising. This happens because a similar. if not the same, legislative adjustment in the field of indirect taxes does not offer the member states a greater choice as for manoeuvres and thus not even the possibility to reach the average values of the EU countries to a larger extent.

Unlike indirect taxes, the direct taxation field (i.e. especially the corporation taxes or payroll taxes) is affected by the European harmonisation trend only marginally. The cooperation of member states comes through especially when providing information on taxes, avoiding double taxation, taxation of interest or licence fees or when fighting tax havens. At the European level, there have been fruitless discussions for several years concerning the adoption of the directive adjustment of the common consolidated tax base of corporations (the rate would remain in the discretion of member states), which was strongly rejected by a number of states. Member States perceive the field of income taxation as a part of their national sovereignty which has been developing for centuries on political, geographical, social as well as humanitarian bases, and this is why the efforts in this field are in most cases accepted with a negative initial attitude in the member states. 
Yet, the high rates in the model ( $d C I T$ with the value of $0.985, d P I T$ with 0.973 and $d$ Payroll with the value of 0.551) suggest that they have a greater influence on the tax burden convergence than harmonised indirect taxes. Their share in the total tax burden in the EU ranges on average around $30 \%$ and it does not differ much from the indirect taxes shares. To justify the degree of this impact, it is also necessary to look at the other side and point out that in the field of income taxes, there is still tax competition in the EU. The tax competition formulation is dealt with by Szarowská [13] who understands it in the same way as the author of the current paper does, or as: "A process of lowering effective tax burden to make investors and factors of production owners allocate their tax bases in a given country, provided that identical conditions are respected for all subjects."

It is also noteworthy in this area that it is the tax competition, which is supported especially by the efforts of the less developed or new member states to do well on the European market. For that reason, it is possible to observe relatively low rates concerning income taxes in accession countries (e.g., Bulgaria in 2004, Czech Republic, Lithuania, etc.) in comparison with the EU average. They result in the outflow of tax bases from their original residual homelands, which forces the original residual states to establish countermeasures not to allow the outflow of tax bases, or to beguile these tax bases back.

As follows from the $\sigma$-convergence graph of personal income taxes in the works by Bušovská [24] and Plojhar [42], there is a clearly visible decrease of the tax level of income taxes in the EU countries, especially in the 1980 s up to 2011 . The decrease in rates occurs during the whole period, starting in the very half of 1980s new new economic approach of supply side. They were trying to reduce the economic policy by the support of factors of production owners who create economic wealth, or more precisely people who produce goods and services. The fundamental idea of supply side economics is the hypothesis that the offer of factors of production is much more flexible than it was assumed by Keynesian economics, which either ignored it completely or considered it negligible. The change of tax rates will arouse various changes the behaviour of an individual.

The first change is the retirement effect reflecting the fact that to maintain their living standards, an individual increases their working efforts when tax rates increase and vice versa. The second change is the substitution effect that expresses the willingness to reconcile with lower wages accompanied by more free time. The key point is the statement that the changes of marginal tax rates cause changes in prorated labour costs and savings, and thus they also cause changes in their offering.

The degree of influence of income and labour force taxes confirms the conclusion of Kubátová [10] that it is not necessary to harmonize taxes artificially since tax competition can lead to the so called spontaneous harmonization effect, and, theoretically, also to a greater effectiveness of tax systems when the competition of taxation systems brings the increase of economic stimuli of individual taxes as well as to saving of the public budgets. In this case, the assumption that tax competition really has an impact on the tax burden convergence in the European area was confirmed.

The degree of influence of social security contributions $(S C)$ on convergence is positively dependant (0.0607) at a lower than $1 \%$ importance level. Nevertheless, no great harmonisation pressure occurs in the field of insurance in the EU. There is only coordination or rather the same application of several basic rules. e.g., equal treatment, the only insurance in the EU area, the addition of insurance periods, the payment of benefits, the assimilation of facts and good administrative cooperation. Obviously, it is not the same application of rules, but only a certain general frame of the international operation of social insurance in the EU. Thus there is no application of harmonisation rules in this field since every country uses its 
own procedures which are based on historical, sociological as well as on political roots. That is why even the degree of the influence on the tax burden convergence is not noticeable.

The last analysed variable which showed a positive influence on the effective tax burden convergence in the EU is represented by the property tax revenues (dProperty with the value of 1.025). Bušovská [24] points out to the tax mix convergence in the EU between 1965 and 2011 and mentions that in the tax zone of property taxes, the convergence was confirmed by $\beta$-convergence, but $\sigma$-convergence in the graph is faint. Nonetheless, it is impossible to say that the divergence occurs because - according to Slavík [32] - if $\beta$-convergence is confirmed, $\sigma$-convergence only depicts its picture.

The number of property taxes and rates of these taxes have always differed most in Europe. In some countries, they were very high, in others there were almost none. The attitude of domestic governments to individual taxes was and has been different. Although in some countries an opinion prevailed that there should be almost no property taxes because double income taxation occurs, other states praised their indisputable influence and the function of solidarity in society. Despite these great differences, the development took place in the field of property taxes from 1965 to 2011 and although property taxes differ within the EU and there are still lots of them, we can currently observe that several main types of property taxes have been generated which are embraced by the legislatives of most European countries. Thus the most frequent property taxes in the EU include land tax, building tax, inheritance tax, gift tax, property transfer tax and wealth tax.

\section{Conclusion}

The aim of the work was to find out to what degree the components of the effective tax burden (compound tax quotas) influence the tax system convergence and to what degree the tax system convergence is influenced by tax competition in the EU. The individual parts of the compound tax quota were divided in accordance with the OECD classification into income taxes (IT), payroll taxes (Payroll), social contributions (SC), indirect taxes (Indir), property taxes (Property) and other taxes (Other). The subject of research was a panel of 28 countries between 1965 and 2011 and the missing data were not considered.

To meet the objectives, an analysis of available literature was completed allowing the definition of tax competition. Secondary data from the OECD database for 1965-2011 were used and subsequently applied to a panel regression analysis with fixed effects. Two models were designed, both of which showed significant dependence on significance level lower than $1 \%$. Moreover, according to the Durbin-Watson test, the model does not suffer from residual autocorrelation and work with stationary time series.

The model provides a proof of positive dependence of fixed residues when 719 observations were made. The outcomes confirm that all parts of a tax mix and their changes affect tax burden convergence in the EU. Surprisingly, the greatest influences are shown by property taxes where, in the period under consideration, six main groups were generated from the originally enormous number of taxes and these are currently used in all member states. Indirect taxes convergence does not have as great an impact over effective tax burden convergence as one would expect, which is a consequence especially of high harmonization measures applied since the very establishment and implementation of indirect taxes in the legislation of European states.

When understanding tax competition in accordance with Szarowská [13] high values of the dependence of income and payroll taxes (dCIT, dPIT and Payroll) in the model indicate that tax competition has a greater influence on the tax burden convergence than tax harmonisation 
or coordination which are direct taxes at a relatively low level because of the sovereignty restriction of the member states.

The degree of the influence of corporate income taxes, personal income taxes and labour taxes confirms the conclusion of Kubátová [10] that taxes do not need to be harmonised artificially as tax competition can lead to the so called spontaneous harmonisation effect and. theoretically, also to the greater effectiveness of tax systems when the competition of taxation systems leads to the increase of economic stimuli of individual taxes and saves public budgets, which was also proved in the work by Szarowská [13]. In this case, the presumption was confirmed that tax competition has a truly great impact on the growth of the gross domestic product in Europe.

The conclusions above justify that the tax burden convergence is influenced by all applied taxes; yet, the greatest share of the tax burden convergence was borne by tax competition and property taxes between 1965 and 2011 and although one would think that the impact of indirect harmonized taxes should be the greatest, it is not the case.

Although tax burden convergence is actually influenced by many more factors than only by its structure, the values of the adjusted determination coefficient of the estimated model ranged from $58 \%$. The model also satisfies diagnostic tests and thus it is so robust from, the econometrical point of view. Hence the estimated results can be considered relevant with a satisfactory explanatory power.

The model results from works of authors stated above which do not absolutely reflect the impact of other variables that have an effect on the tax convergence in the EU that will be part of further research (e.g. other macroeconomic indicators, adoptions of European laws, the acceptance of new members, etc.). The basis of the whole work is the methodology of new Keynesian economics according to which the econometric model used can only help reveal the relations among variables, but its conclusions do not confirm nor disprove the validity of the economic theory. That is why recommendations for the economic policy cannot be drawn from the outcomes of the model. The work does not deal with fairness or equality in the field of taxes, nor does it aim at suggesting an appropriate tax policy for the member states of the EU. The work provides a basis for further possible research in the same direction when it is possible to include additional variables in the model, e.g., the mobility of labour or the influence of the harmonisation legislative on the tax policy within the European Union.

\section{Acknowledgment}

This paper was written in relation with the project of the Department of Public Finance at the Faculty of Finance and Accounting IGA F1/2/2013 titled "The Public Finance in Developed Countries".

\section{Literature}

[1] EUROEAN COMMISION: Konsolidované znění smlouvy o fungování Evropské unie. 2010. Available from WWW: lex.europa.eu/LexUriServ/LexUriServ.do?uri=OJ:C:2010:083:0047:0200:cs:PDF

[2] HELÍSEK, M.: How Far Along is Euro Adoption in the Czech Republic? Benefits for Businesses Still Remain. Central European Business Review. 2013. Vol. 2, pp. 21-27. ISSN 1805-4854.

[3] EMERSON, M.; GROSS, D.; ITALIANER, A.: One market, one money. An evaluation of the potential benefits and costs of forming an economic and monetary union. Oxford University Press. 2010. 
[4] MUSGRAVE, P. B.: Tax Policy in the Global Economy. Cheltenham: Edward Elgar Publishing. 2002. 470 pp. ISBN 9781840643138.

[5] SERNA, G. R.: State Corporate Tax Policy: Is Tax Competition the Main Determinant? PA 796. Independent Study. [online]. [accessed 2015-02-10]. 2008. Available from WWW: http://www.martin.uky.edu/centers_research/.../Serna.pdf

[6] LÁCHOVÁ, L.: Daňové systémy v globálním světě. $1^{\text {st }}$ edition. Prague: ASPI. 2007. 271 pp. ISBN 978-80-7357-320-1.

[7] KUBÁTOVÁ, K.: Daňová teorie a politika. $5^{\text {th }}$ updated edition. Prague: Wolters Kluwer Czech Republic. 2010. 275 pp. ISBN 978-80-7357-574-8.

[8] MACH, P.: Daňová konkurence musí být zachována. 2004. Available from WWW: http://www.petrmach.cz/node/52

[9] REUVEN, A. S.: Tax Convergence and Globalization. Michigan Law. [online]. University of Michigan Law School. 2010. Vol. 214. [online]. [accessed 2015-02-10]. Available from WWW: http://papers.ssrn.com/sol3/papers.cfm?abstract_id=1636299

[10] KUBÁTOVÁ, K.: Daně - konkurence nebo harmonizace? Conference Proceedings: Tax Harmonisation vs. Tax Competition. Prague: Centre for Economics and Politics. Proceedings Nr. k. č. 29. 2004. pp. 51-60. ISBN 80-86547-29-9.

[11] TEATHER, R.: The Benefits of Tax Competition. London: The Institute of Economic Affairs. 2005. pp. 91. ISBN 0255365691.

[12] NERUDOVÁ, D.: Harmonizace daňových systémů zemí Evropské unie. $2^{\text {nd }}$ updated edition. Prague: ASPI. 2008. 257 pp. Daňová řada. ISBN 978-80-7357-386-7.

[13] SZAROWSKÁ, I.: Daňová konkurence v Evropské uni a její vlivy na vybrané ekonomické veličiny. Dissertation. Karviná, 2011.

[14] FOLTYSOVÁ, M.: Zmena daňových mixov v OECD krajinách vplyvom meniacich sa podmienok globalizujúceho sa sveta. Dissertation. University of Economics in Prague. Prague, 2007.

[15] KUBÁTOVÁ, K.; VANČUROVÁ, A; FOLTYSOVÁ, M.: Impact of Globalization on Taxation Mixes in OECD Countries During 1965-2003. Prague Economic Papers. 1(17). 2008. pp. 40-52. ISSN 1210-0455.

[16] De BANDT, O.; MONGELLI, P.: Convergence of fiscal policies in the euro area. ECB Working $\quad 2000.2$ Available from http://papers.ssrn.com/sol3/papers.cfm?abstract_id=355580

[17] SOSVILLA, R.; TAMARIT, C.: Un análisis empírico del proceso de convergencia fiscal en la Unión Europea. Hacienda Pública Española. 1999. 150. pp. 127-146.

[18] SOSVILLA, R.; TAMARIT, C.: Convergence in fiscal pressure across EU countries. Applied Economics Letters. 7(2). 2000. pp. 117-123.

[19] SOSVILLA, R.; SIMÓN, G. M.; ÁNGEL, A. M. J.: Tax burden convergence in Europe. Estudios de Economía Aplicada. 2001. Vol. 17., pp. 183-191.

[20] DELGADO, J. D.; PRESNO, M. J.: Presión fiscal en la Unión Europea: un análisis de beta. sigma y gamma convergencia. Revista de Economía Mundial. 2009. pp. 141-166. Available from WWW: http://dialnet.unirioja.es/servlet/articulo?codigo=3106518 
[21] DELGADO, J. D.; PRESNO, M. J.: Convergence of the fiscal pressure in the European Union: a time series approach. Working Paper 19/07. 2007. Instituto de Estudios Fiscales. Madrid.

[22] RIVERO, F. J. D.; CASQUERO, M. J. P.: Tax policy convergence in EU: an empirical analysis. Revista de Economía Mundial. 2010. 26. pp. 53-83. Available from WWW: http://dialnet.unirioja.es/servlet/articulo?codigo $=3600337$

[23] BUŠOVSKÁ, M.: Convergence of VAT Rates within the EU Integration. In: Teoretické a praktické aspekty veřejných financí (Theoretical and Practical Aspects of Public Finance). Prague: Publishing House Oeconomica. 2012. ISBN 978-80-245-1764-3.

[24] BUŠOVSKÁ, M.: Convergence of Tax Burden. Tax Revenues and Implicit Tax Rates in the European Union Countries. Ekonomický časopis. 2014. Vol 4. pp. 363-376.

[25] BUŠOVSKÁ, M.; PETROVICKÁ, I.: Convergence of Tax Revenues in the European Union. ACC Journal. 2013. Vol. XIX, Issue 2, pp. 18-28. ISSN 1803-9782.

[26] BLECHOVÁ, B.: Charakteristika př́stupu používaných $\mathrm{V}$ EU pro hodnocení efektivního daňového zatížení př́ijmů korporací [CD]. 2008. In: Teoretické a praktické aspekty veřejných financí. Prague: VŠE. ISBN 978-80-245-1378-2.

[27] EUROEAN COMMISION: Taxation trends: 2012. 2014. [online]. [accessed 2015-0208]. Available from http://ec.europa.eu/taxation_customs/taxation/gen_info/economic_analysis/tax_structure s/index_en.htm

[28] ŘÍHOVÁ, L.: Výnosy korporátní daně v zemích OECD a faktory které je ovlivňují. Dissertation. University of Economics in Prague. Prague, 2008.

[29] PETRÁŇOVÁ, L.: Implicitní daňové sazby v ČR - komparace se státy EU. Thesis. University of Economics in Prague. Prague, 2009.

[30] OECD: Tax Revenue Statistics 2012 edition. [online]. [accessed 2015-02-10]. 2012. Available from

WWW: http://www.oecd.org/tax/taxpolicyanalysis/oecdtaxdatabase.htm\#ssc

[31] KUBÁTOVÁ, K.: Typologizace daňových mixů v zemích OECD. Littera Scripta. 2012. Vol. 5, No. 2, pp.75-82. ISSN 1802-503X.

[32] SLAVÍK, C.: Reálná konvergence České republiky k Evropské unii v porovnání s ostatními novými členskými zeměmi. Politická ekonomie 1/2007. Available from WWW: http://www.vse.cz/polek/abstrakt.php3?IDcl=588

[33] NOVÁK, P.: Analýza panelových dat. Acta Oeconomica Pragensia. 2007. Vol 1, pp. 71-78.

[34] LEVIN, A.; LIN, C. F.; CHU, C.: Unit Root Tests in Panel Data: Asymptotic and Finite-Sample Properties. Journal of Econometrics. 2002. pp. 1-24.

[35] IM, K. S.; PESARAN, M. H.; SHIN, Y.: Testing for Unit Roots in Heterogeneous Panels. Journal of Econometrics. 2003. pp. 53-74.

[36] MADDALA, G. S.; WU, S.: A Comparative Study of Unit Root Tests with Panel Data and A New Simple Test. Oxford Bulletin of Economics and Statistics. 1999. Vol. 61, pp. 631-652.

[37] CHOI, I.: 2001: Unit Root Tests for Panel Data. Journal of International Money and Finance. 20, pp. 249-272. 
[38] DOUGHERTY, Ch.: Introduction to Econometrics. Oxford: Oxford University Press. 2006. 480 pp. ISBN 978-0-19-928096-4.

[39] DAVIDSON, R.; MacKINNON, J.: Testing for consistency using artificial regressions. Economic Theory. 1989. Vol. 5, pp. 363-389. ISSN 0938-2259.

[40] DURBIN, J.; WATSON, G. S.: Testing for Serial Correlation in Least Squares Regression. Biometrika. 1951. Vol. 38, pp. 159-179. ISSN 0006-3444.

[41] WOOLDRIDGE, J.: Introductory Econometrics: A Modern Approach. Michigan State University, 2006. 888 pp. ISBN-13: 9780324581621.

[42] PLOJHAR, M.: Konkurence ve zdanění podniků v rozšířené EU. Seminář Daňová harmonizace vs. daňová konkurence. 13.01.2014. [online]. [accessed 2015-02-15]. Available from WWW: http://cepin.cz/cze/prednaska.php?ID=467

[43] WYPLOSZ, Ch.; BALDWIN, R.: Ekonomie evropské integrace. $4^{\text {th }}$ edition. Prague: Grada Publishing. 2013. 580 pp. ISBN 978-80-247-4568-8. 


\section{JaKÝ Vliv MAJí JeDNOTLIVÉ DANĚ NA KONVERGENCI DANÍ V EU?}

Z původní čistě ekonomicky orientované spolupráce se zrodila komunita s názvem Evropská unie, která nyní spolupracuje $\mathrm{v}$ celé řadě oblastí a ani daňová politika není výjimkou. Tento článek vychází z prací, které poukazují na daňovou konvergenci v EU. Cílem je kvantifikovat vliv daňového mixu a daňové konkurence na sbližování daňových systémů $\mathrm{v}$ EU. Empirická část práce využívá panelové regrese s fixními efekty pro 28 zemí EU v letech $1965-2011$. Dva sestrojené modely vykazují statisticky významný pozitivní vliv všech determinantů na konvergenci efektivního daňového zatížení. Nejdůležitějšími faktory daňové konvergence jsou dle výsledných hodnot daňová konkurence a majetkové daně. V̌šchny modely splňují diagnostické testy a jsou ekonometricky robustní. Výsledky mohou být považovány za relevantní s dostatečnou vypovídací schopnosti.

\section{WIE EINZELNE STEUERN DIE KONVERGENZ DER BESTEUERUNG IN DER EUROPÄISCHEN UNION BEEINFLUSSEN}

Die ursprüngliche rein wirtschaftlich orientierte Zusammenarbeit gab Geburt einer Gemeinschaft mit dem Namen der Europäischen Union, die nun in einer ganzen Reihe von Bereichen zusammenarbeitet und die Steuerpolitik ist dabei nicht ausgeschlossen. Dieser Beitrag ergibt sich aus Arbeiten, die auf eine Steuerkonvergenz in der EU hinweisen. Das Ziel dieser Arbeit ist es, die Auswirkungen des Steuer-Mix und des Steuerwettbewerbs auf die Konvergenz der Steuersysteme in der EU zu quantifizieren. Der empirische Teil des Artikels nutzt Panelregressionen mit festen Effekten für die 28 Länder der EU in den Jahren 1965 2011. Zwei Modelle weisen einen statistisch signifikanten positiven Einfluss aller Komponenten auf die effektive Steuerbelastung aus. Die wichtigsten Determinanten der steuerlichen Konvergenz sind nach den resultierenden Werten der Steuerwettbewerb und die Grundsteuern. Alle Modelle erfüllen die diagnostischen Tests und sind ökonometrisch robust. Die Ergebnisse können, da sie über ausreichende aussagekräftige Fähigkeiten verfügen, als relevant betrachtet werden.

\section{JAKI JEST WPŁYW POSZCZEGÓLNYCH PODATKÓW NA KONWERGENCJĘ PODATKOWĄ W UE?}

Współpraca zorientowana początkowo tylko na aspekty gospodarcze przekształciła się we wspólnotę o nazwie Unia Europejska, w ramach której współpraca podejmowana jest w wielu dziedzinach, w tym $\mathrm{w}$ zakresie polityki podatkowej. Niniejszy artykuł oparty jest na opracowaniach poświęconych konwergencji podatkowej w UE. Celem opracowania jest kwantyfikacja wpływu mixu podatkowego i konkurencji podatkowej na zbliżanie systemów podatkowych w Unii. W empirycznej części pracy zastosowano regresje panelowe z efektami stałymi dla 28 państw UE w latach 1965 - 2011. Dwa opracowane modele wskazują na statystycznie istotny pozytywny wpływ wszystkich determinant na konwergencję efektywnego obciążenia podatkowego. Na podstawie analizy uzyskanych wartości można stwierdzić, że do najważniejszych czynników wpływających na konwergencję podatkową należy konkurencja podatkowa i podatki majątkowe. Wszystkie modele spełniają testy diagnostyczne i są ekonometrycznie wiarygodne. Wyniki można uznać za odpowiednie o wystarczającej wiarygodności. 